\title{
Preservation in the Digital Age
}

\section{A Review of Preservation Literature, 2009-10}

\author{
Karen F. Gracy and Miriam B. Kahn
}

This paper surveys research and professional literature on preservation-related topics published in 2009 and 2010, identifies key contributions to the field in periodicals, monographs, and research reports, and provides a guide to the changing landscape of preservation in the digital age. The authors have organized the reviewed literature into five major areas of interest: tensions in preservation work as libraries embrace digital resources, mass digitization and its effects on collections, risk management and disaster response, digital preservation and curation, and education for preservation in the digital age.

Submitted July 5, 2011; tentatively accepted for publication, pending modest revisions August 15, 2011; revision submitted September 20, 2011 and accepted for publication.

Karen F. Gracy (kgracy@kent.edu) is Assistant Professor, Kent State University, School of Library and Information Science, Kent, Ohio; Miriam B. Kahn (mbkcons@netexp.net) is Adjunct Faculty, School of Library and Information Sciences, Kent State University, and Preservation Consultant, MBK Consulting, Columbus, Ohio.
$\mathrm{T}$ his review article critically examines the literature of preservation published during a two-year period, 2009-10. Almost a decade has passed since the last review of the preservation literature appeared in Library Resources and Technical Services, covering the period of 1999-2001. ${ }^{1}$ In the interim, the evolution of the preservation field noted by Croft has accelerated, encompassing whole areas of practice that were in their infancy at the turn of the twenty-first century. In her review, Croft identified ten areas of emphasis in the literature: clarifying preservation misconceptions triggered by the publication of Nicholson Baker's Double Fold; the continued importance of the artifact in the wake of new digital reformatting technologies; remote storage; mass deacidification; physical treatment and commercial binding; contingency planning, environmental control, and integrated pest management; unique formats (including audiovisual media); preservation reformatting; educational endeavors; and digital technology and preservation. ${ }^{2}$ While the impact of digital technologies was briefly addressed by Croft, primarily as the technique poised to replace microfilming as the reformatting method of choice, little attention was devoted to the development of theory and techniques for preserving born-digital materials or even the preservation of those digital surrogates resulting from the conversion of analog materials. ${ }^{3}$

In a remarkably short period, the professional discourse has changed utterly from the world described by Croft. Digitization is no longer an emerging tool; it is the established and often preferred method for reformatting. ${ }^{4}$ The emergence of Google as a key player in mass digitization of collections forced a shift in priorities for many libraries away from building and maintaining physical collections toward an emphasis on the creation of access avenues through the licensing of burgeoning digital collections of journals, books, and multimedia. These advances 
coincide with other trends in library collections practices, including reducing the footprint of collections to make room for more seating in the library and more service areas and increased collaboration on last-copy print archiving.

Meanwhile, journal articles, research reports, conference proceedings, and technical literature reporting the latest development in digital preservation and the closely related area of digital curation have flowered in the last decade, resulting in a refocusing and broadening of the field to encompass new tools, techniques, and issues. In addition, recent developments in preservation education-particularly in the areas of digital preservation and curation-have resulted in discussion of how best to address needs for education and training as librarians and archivists care for hybrid collections of both analog and digital material.

\section{Scope of the Review}

While scanning the literature for this project, the authors initially cast a wide net to assess the degree to which the field has changed and expanded in the last decade. Techniques used to identify relevant literature included searching in relevant databases (such as Library Literature and Information Science Full Text and Library, Information Science and Technology Abstracts), scanning tables of contents of pertinent journals, examining publishers' websites to identify recent new monographs, collecting reports from organizations known to be involved in preservation-related research, and monitoring electronic discussion lists devoted to preservation and digital preservation issues. ${ }^{5}$ This search uncovered more than 600 English-language sources published in the two-year period covered by this review. While the emphasis is still on research-oriented publications, changes in knowledge dissemination within the preservation field required the inclusion of many more electronic resources than were covered in past reviews, particularly in the areas of digital preservation and curation. This paper summarizes developments reported in the following genres: research articles, book chapters, and monographs; theoretical articles, book chapters, and monographs; substantial think pieces, including editor's introductions to journal issues and books; research reports; and certain articles appearing in the technical and professional literature (excluding some types of literature, detailed below).

The authors complied a subject bibliography, available online, which includes citations to those materials that could not be reviewed in this paper given space limitations of the journal. ${ }^{6}$ Categories of resources included in the online bibliography, but not this review, include technical leaflets, conference proceedings, audio and video (multimedia) resources, and web resources such as blogs and portal sites. The authors specifically excluded the following resource categories from this review and the supplementary online bibliography: book reviews; announcements; brief news articles (such as one would find in American Libraries, Library Journal, LC Information Bulletin, D-Lib Magazine, etc.); brief editorials and opinion pieces, except for substantive editor's introductions as noted above; and reports on reformatting projects, unless they have been identified by the authors as case studies in best practices for digitization.

The authors organized the literature into five major areas of interest: The Physical and the Virtual: Libraries and Collections in Transition; Mass Digitization and Its Impact on Preservation Activities; Risk Management; From Preservation to Curation: Lifecycle of Digital Materials; and The New Preservationist.

\section{The Physical and the Virtual: Libraries and Collections in Transition}

One overarching trend that has influenced the practice of preservation in libraries and archives during 2009-10 is the continuing, quickly accelerating transition of collections from the traditional library, where physical objects are primarily managed onsite, to the hybrid library. In the latter model, legacy collections continue to be maintained, often at offsite storage facilities, but development and growth of electronic collections are increasing rapidly. ${ }^{7}$ These adjustments to the focus of collections and the nature of the library have significant repercussions for preservation activities and programs.

Despite the emphasis now being placed on digital collections and the virtual library, physical collections are still present and will continue to be around for many years, particularly archival and special collection material. Traditional methods of stabilizing the physical object for handling and use are still important to the well-being of collections and essential to researchers. Conservators continue to work on objects, paper, books, and textiles in an effort to repair and retard natural deterioration or provide appropriate housing for long-term storage. Thus the literature of preservation continues to address key issues surrounding the care of the physical artifact. In this section, and the following two sections, the authors address the preservation of the physical object and the maintenance of physical collections.

The literature also exposes the struggles of preservationists and conservators to integrate the demands of digitization and digital preservation with the responsibilities that physical preservation work already presents. Digital endeavors in the library alternately contribute to and compete with traditional preservation work in terms of resources. New projects either stand in isolation as concerns about the physical condition of materials and their longevity or are paired with a digital component to provide access 
to the intellectual content. This interconnectedness makes a review of the physical or traditional side of preservation literature difficult to separate from the new digital preservation initiatives, although in this literature review the authors sometimes sorted the literature in a way that may make activities in the field seem more circumscribed than they are in practice.

\section{The Physical Artifact}

The research and professional literature that deals with physical preservation and conservation reflects the maturity of this field in dealing with its perennial challenges: how best to safeguard collections by improving storage conditions and reducing damage from misuse, how to carry out treatments aimed at increasing the lifespan of circulating materials, and how to stabilize and protect fragile materials. Many articles merely synthesize and restate established information and standards for the preservation and conservation field. ${ }^{8}$ These articles tend to be aimed at international audiences and new practitioners, providing rudimentary guidelines and standards for preservation and increasing the longevity of collections. Topics such as inherent vice and the need for stable environmental conditions are discussed in detail, with appropriate suggestions for reducing external causes of deterioration. (The Society of American Archivists' Glossary of Archival and Records Terminology defines inherent vice as "the tendency of material to deteriorate due to the essential instability of the components or interaction among components." $)$ While the studies and projects may be new, the information imparted and results presented are familiar to long-time practitioners in the field.

The underlying imperative for many of these basic articles is the need for a preservation program or policies in all libraries. Most provide ammunition for instituting or continuing preservation programs that focus on longevity for collections, training in care and handling or basic repair techniques, and often, justification for preserving digital collections. ${ }^{10}$ While these articles accomplish the goal of conveying core preservation knowledge, they frequently do not discuss the costs of implementing preservation programs in an era of stagnant or shrinking budgets and insufficient staff resources.

\section{Treatments and Binding}

While all conservation literature published in the last two years is outside the scope of this review, the authors wish to draw readers' attention to several key resources that will be of interest and direct them to the web bibliography for a more complete list of articles in this area. Restaurator, and various publications of the American Institute of Conservation and the International Institute for Conservation of Historic and
Artistic Works, continue to be significant sources of information about conservation work. Other sources that are new on the conservation scene are several electronic journals (CeROArt, E-Conservation Magazine, and e-Preservation Science Journal) that often include articles on library and archival material, particularly paper-based objects. ${ }^{11}$

Conservators often write about ethical issues surrounding the selection of appropriate treatments. Articles about treatments usually contain descriptions of conservation of individual items together with vibrant discussions of decision-making and techniques and their associated risks to the integrity or aesthetics of the object in question. For example, Brückle considers the benefits and risks associated with bleaching of paper documents and notes how conservators must always balance a treatment's desired aesthetic outcome with its potential for harm to the physical structure of the object: "Deciding on a bleaching treatment requires the conservation expert to foresee the results of prospective treatment both technically and aesthetically, a prognosticative ability that always functions as an advance screening tool by which the risk of treatment can be minimized."12

Surveying and documentation continue to be cornerstones of good conservation and preservation practice. As Fischer writes, "Documentation is considered a basic requirement and an essential component of any conservation measure. ${ }^{\prime 3}$ Conservators such as Hanus and colleagues and Liu and Wang also describe surveys of the condition and content of materials under consideration for conservation treatment and how the results of those surveys play a critical role in the identification of at-risk materials and the selection of objects for conservation. ${ }^{14}$ The most focused conservation articles deal with specific treatments accompanied by histories of the object or its cultural significance. ${ }^{15}$ Depending on the article's audience, additional details include provenance, arrangement, and even how digitization efforts influence the conservation treatments. ${ }^{16}$

Conservation treatments in the form of repairs or application of chemicals for various purposes, such as the removal of adhesives or pollutants, or to counteract the deleterious effects of high levels of acidity in materials continue to be an important tool in the preservation toolkit when item-level action is required. Paper conservation scientists focus on such topics as corrosive inks, removal of pressure-sensitive tape, paper bleaching, document flattening, paper strengthening, deacidification, and cleaning techniques. ${ }^{17}$ In their study of book conservation techniques in research libraries, Baker and Dube note an increased blurring of the lines for treatment of materials. ${ }^{18}$ They observe that conservation work on specific items is now integrated into a workflow of best practices. Rare and valuable artifacts are treated individually when needed by specialists; otherwise, hands-on treatments focus on increasing the longevity of collections and making standard repairs where necessary. 
Significant works in the area of historical binding have recently become available, including books by Etherington, Leutz, Lindsay, and Miller. ${ }^{19}$ Etherington gives historical context for the integration of bookbinding knowledge into conservation. Interviews conducted by Leutz provide insight into current binding practice by contemporary practitioners. Miller's book helps librarians and historians decode the material nature of the bound volume. Lindsay's Fine Bookbinding is sure to become a well-thumbed resource for the book conservator seeking detailed instructions for basic and complex fine binding techniques using leather.

\section{Reformatting Print Materials}

Libraries create surrogates of print materials, also known as use or access copies, for various reasons: to protect originals from further damage, to replace originals if deterioration threatens to make originals unusable, or to enhance access by taking advantage of new technologies that permit analysis and manipulation of originals through, for example, optical character recognition of text to allow searching and magnification of the image.

A number of studies and projects discuss the use of microfilm to provide long-term access to physical content. Articles on this topic range from case studies, guidelines for decision-making, criteria for selecting digital repositories, and discussions of access methods and metadata. ${ }^{20}$ Although microfilm was once the gold standard for reformatting print material and ensuring long-term access to its intellectual content, the survival of microfilming as a preservation tool is now in question. One is more likely to read discussions of how to convert microfilm to digital images than descriptions of new microfilming projects. ${ }^{21}$ Yet microfilming is still used in many newspaper reformatting projects, both to ensure longevity of this information for centuries to come and to reduce the costs of digitization.

Conway has cautiously defined digitization for preservation as "an investment in the creation of lasting digital products," rather than as a method of preserving objects in the traditional sense of stabilizing deteriorating or at-risk materials. ${ }^{22}$ As digitization activities have matured into programs within institutions and among members of consortia, key players in digital libraries and digital preservation have generated numerous best practice documents. Hurst-Wahl suggests that the field may wish to consider developing a universal set of guidelines governing selection, metadata schemas, scanning and quality control, and long-term preservation of resulting digital resources. ${ }^{23}$ This standard could be very beneficial for normalizing practices in digitization and encouraging interoperability. Until the field prioritizes formal standardization of digitization activities, however, new resources such as Bülow and Ahmon's Preparing Collections for Digitization will offer useful compendia of best practices for practitioners and administrators. ${ }^{24}$

\section{Other Media Formats}

While the brittle books crisis dominated the discourse of preservation in the 1980s and 1990s, the fragility of photographic and audiovisual material has become a significant worry for the preservation community during the last decade. Few libraries have media preservation specialists on staff, making assessment of rapidly deteriorating and obsolescing collections difficult. While interest in the content of the material may be strong, lack of expertise and dauntingly high reformatting costs present insurmountable hurdles for many institutions to overcome, particularly as librarians contemplate the needs of audiovisual material. ${ }^{25}$

Libraries and archives face many technical challenges in preserving photographic audiovisual materials. The physical and chemical composition of these materials often leads to their rapid decay, particularly in poor storage conditions, and makes them easily susceptible to damage because of careless handling. Collections of such material are often poorly documented or contextualized, though many contain significant and rare content. ${ }^{26}$ The literature examined for this review reflects the continued interest in providing new information about the nature of deterioration of photographic and audiovisual material, and care on the physical artifact. ${ }^{27}$

The Getty Conservation Institute's recent edited volume on photographic conservation, which covers 150 years of technical information and research about the photographic medium, provides a welcome addition to the reference literature that gathers fundamental research and critical historical documents in one place. ${ }^{28}$ The Getty also published an English-language edition of Lavédrine's helpful catalog of analog photographic processes, from daguerreotypes and heliographs to chromogenic prints and negatives. ${ }^{29}$ This volume also includes information of care of these materials.

Similar comprehensive publications in the area of sound recordings and moving images would be greatly welcomed by preservation specialists; the field suffers from having few authoritative reference sources in this area. The few that have been published are often difficult to procure in North America and many are dated. Instead, the literature of audiovisual preservation often favors case studies of preservation and restoration, which combine historical context of the material being preserved with description of techniques used to play back and make a preservation copy of materials. As part of preservation projects, archivists often must investigate original methods of capturing sound and images, and contend with problems associated with conversion of analog signals to digital formats. ${ }^{30}$ Reports on restoration work and contemplations of the ethics of restoration 
and access often dominate the literature on moving image preservation, revealing an ongoing pattern of self-reflection about the nature of restoration work and how the boundaries between ethical and unethical actions should be drawn. ${ }^{31}$

As Clarke notes, preservation of mixed-format archival collections often requires "compromises between ideal physical conservation treatment, patron usage requirements, and staff resources," given the varying needs of different formats that make up these collections. ${ }^{32}$ Van Ness and Cox report that in the wake of Greene and Meissner's "More Product, Less Process" (MPLP) revolution in archival processing, archivists often find themselves reducing or eliminating routine preservation tasks such as rote removal of rusting staples, separation of photographs from other materials, or flattening folded materials. These day-to-day activities are overshadowed when considering the costs of more expensive conservation treatments. ${ }^{33}$

\section{Preservation Inside and Outside the Library}

As more and more libraries renovate and innovate to take best advantage of the square footage of the physical facility, library administrators are reconsidering the amount of space allotted to collections, service areas, and users. More collaborative working spaces and the ability to accommodate more users in the library rank high on most librarians' wish lists. This reallocation of space often means that fewer physical collections are stored onsite and preservation workspaces may be moved out of the library building.

The shifts in collections and preservation work from onsite to offsite storage can have significant impact on collections and preservation activities. Collaborative efforts between consortiums for collection development have reduced the overall number of copies of many resources, as collections are increasingly shared across many institutions rather than being seen as belonging to only one library. ${ }^{34}$ The Research Libraries Group (RLG) Partnership Shared Print Collections Working Group studied how a shared print policy for intra-collaborative cooperation might be devised ${ }^{35}$ Off-site storage also affects processing of materials. Morris reminds preservation professionals that when fragile materials are newly cataloged before off-site storage, they may require additional protection because of increased use given that patrons are now able to discover those items via the catalog. ${ }^{36}$

At the same time collections are being moved to remote storage, preservation and conservation operations (along with technical services) are being moved out of libraries and archives and into their own buildings. Martyniak surveys academic institutions to understand how they protect collections from the elements, from loss, and from additional damage during these shifts. ${ }^{37}$ She identifies critical issues including devising methods of moving materials from the main libraries to the conservation facility that minimize damage, and tracking rare and special collections as they move from vaults and controlled access reading rooms to labs often miles away. Guill voices concern that archives needing sufficient space for processing and storing collections are now competing with demands to use more of the building for users. ${ }^{38}$ Less square footage devoted to these essential archival activities may have a negative impact in two ways: on archival security, because archival storage may be shifted to less desirable locations like basements and thus exposed to potential disasters such as floods, and on access to collections, because they cannot be processed as quickly with limited work space.

\section{Mass Digitization and Its Impact on Preservation Activities}

\section{The Google Decision}

Google's book search partnership with some of the largest academic and public libraries in the world to digitize a significant corpus of their collections significantly affected the direction and scope of digitization projects and programs in libraries. While institutions once contemplated how they would be able digitize more than a small percentage of their collections because of prohibitive cost and copyright restrictions, universal access to much of the world's knowledge seems within everyone's grasp within the next decade, thanks to the efforts by Google and other consortia such as the Open Content Alliance. ${ }^{39}$ While intellectual property concerns continue to provide roadblocks to material still under copyright (see below), the technical and economic challenges seem to have been mostly resolved. Even the naysayers who worried about the fate of digitized materials, should Google no longer be a player in the years to come, may be at least partially reassured by the founding of HathiTrust (www.hathitrust.org) in October 2008, a nonprofit organization devoted to the long-term preservation of products of Google Books and the Internet Archive digitization initiatives. ${ }^{40}$

\section{Mass Digitization, Preservation, and Libraries}

Ignoring the projected impact that Google Books and other large-scale digitization activities will have on preservation activities in libraries is difficult. Conway, summarizing the findings of Rieger's report on mass digitization, foresees that

most library books will reside in remote storage facilities, traditional preservation functions will reorient to support digitization quality control, and the artifactual value of books will pale in compari- 
son to their digital surrogates_-readily available for print-on-demand services but stripped of their tangible connection to their origins and history. ${ }^{41}$

He argues that the enthusiasm for online access to an everincreasing number of books and other materials should be tempered by the sobering realization that librarians and users may be sacrificing certain types of information about objects themselves and the circumstances of their creation in a ravenous desire for quick and easy access to the content they contain.

Large-scale digitization shifts priorities and requires difficult decisions about resource expenditures. Conway notes a series of dilemmas that mass digitization efforts have engendered. ${ }^{42}$ In a time of flat or declining budgets where most preservation dollars are spent on controlling environmental conditions in storage facility, administrators will have to choose between funding digitization activities and funding conservation treatments with the few resources left over in the preservation budget. Preservation-quality digitization, with its high standards for creation of acceptable surrogates that emphasizes full information capture, may be swept aside to increase productivity for digitization projects. Analog audiovisual material, which libraries are eager to have in more accessible formats, may become the victim of poor digitization decisions, which are made in absence of standards for audiovisual analog-to-digital conversion. The library and archival communities face a serious skills gap in the labor force in the areas of digitization and digital preservation, which is forcing institutions to use outside talent (i.e., vendors) until the profession has developed a critical mass of new information professionals equipped to manage this work, which may lead to declines in quality of work performed.

\section{Renewed Focus on Special Collections Materials: Revealing "Hidden" Treasures}

Because Google has taken the lead in converting print material to digital form, libraries have now turned their concerns to those materials that are not so easily scanned, indexed, or served to the masses. Providing digital access to special collections material in libraries and archives has become the new challenge for institutions in recent years. As Lynch states, "special collections are a nexus where technology and content are meeting to advance scholarship in extraordinary new ways. ${ }^{" 43}$ Digitization of historically and culturally significant manuscripts and visual materials allows researchers to use tools of analysis, such as text mining, visualization, and image enhancement, creating new avenues of inquiry that were previously inconceivable. ${ }^{44}$

In placing their attention on digitizing special collections and archival material, institutions hope to bring to light materials that were previously "hidden"-i.e., inaccessible for reasons of lack of documentation, obsolete formats, poor physical condition, or other barriers. ${ }^{45}$ Libraries and archives also have the opportunity to work collaboratively in bringing together materials of the same provenance that are physically held by various institutions; this endeavor has been described as virtual unification. ${ }^{46}$ Collaboration with users of digitized material can result in increased contextualization of digitized material through added metadata and annotation. ${ }^{47}$ Despite the benefits and opportunities that digitization of these hidden collections brings, libraries also must be wary of hidden costs, among them the expenses incurred to ensure long-term retention of the digital master files and the potential for damage to digitized originals as users increasingly seek the original after viewing the digital surrogate.

The fragility of special collections material can make digitization of these materials difficult. Deterioration and damage found in the original objects can introduce errors into digitized images of documents, which must be corrected using image processing technologies. ${ }^{48}$ Special collections material requires significant item-level assessment to identify potential problems before scanning and also may need conservation treatment before digitization as well as significant postproduction descriptive work. All of these concerns make such material less amenable to systemization and streamlining. ${ }^{49}$

Rieger identifies a number of "principles of engagement" that must be considered before launching large-scale digitization initiatives for special collections and archival material, among which she lists the importance of developing a business plan to establish institutional principles, setting digitization specifications that "accommodate the versatile nature of special collections," and weighing the consequences of quality control decisions. ${ }^{50}$ The wisdom of her directives should provide guidance to institutions contemplating collaboration with commercial partners on special collections digitization initiatives.

\section{Legal Roadblocks to Large-Scale Digitization Initiatives (Copyright)}

Copyright restrictions often present a significant barrier to digitization projects. While digitization of public domain materials is relatively straightforward and unproblematic from the perspective of being able to copy and distribute a work online freely, other materials require permission of the copyright holder or holders. ${ }^{51}$ For institutions wishing to digitize material, determining the copyright status of a published work can be time-consuming. If the publication date cannot be verified, or if the copyright owner cannot be found for a publication that should still be under copyright according to current laws, the library may decide not to move forward with digitization and digital distribution plans. 
For those institutions that have been working with Google to gain access to digital copies of large parts of their collections, the recent overturning of the Google Book Search Settlement Agreement means that Google may be less likely to digitize orphan works whose copyright status cannot easily be determined. Lavoie and Dempsey, in their study estimating the number of books potentially still under copyright in library collections, could not determine how many orphan works may be lurking in the more than 12 million post-1923 books found in U.S. academic libraries, but suggest that if even 10 percent of that figure were orphans, the costs to research their copyright status would be significant and potentially be a deterrent to digitization of these materials. ${ }^{52}$

While the copyright issues surrounding book scanning and digital distribution have received the lion's share of attention in recent years, the problems are equally acute for unpublished works that archives and libraries wish to digitize. For special collections materials, the amount of time required to contact rights holders to request permission to display digitized material online also can be very time-consuming and potentially very expensive. Akmon reports that the biggest obstacle to getting permission is nonresponse to requests. ${ }^{53}$ Archives have traditionally considered nonresponse the same as refusal to grant permission, and Akmon suggests that archives may want to reconsider this extremely risk-averse stance, as it means that significant percentage of documents in archival collections (sometimes as much as 30-40 percent of collections) cannot be made available to users online. Dickson reports similar difficulties with copyright clearance for archival materials and also recommends that a new definition of due diligence for manuscript and archival collections be developed that will define reasonable effort in copyright search and make it easier and less expensive to make such material available online. ${ }^{54}$

\section{Risk Management}

\section{Environmental Conditions and Collections Care}

Several articles reviewed for this project report on the effects of environment on collections, including the importance of establishing stable environmental conditions within cultural institutions, monitoring fluctuations, and selecting the appropriate monitoring devices or heating, ventilation, and air conditioning (HVAC) systems. Chang and Falk studied the stability of environments in mid twentieth-century buildings. ${ }^{55}$ Their survey and subsequent analysis emphasizes the need for collaborative efforts "to design more environmentally sound archive spaces. ${ }^{156}$ Researchers also have examined the effects of air pollution and airborne fungi on deterioration of collections. ${ }^{57}$
Readers attempting to reduce vandalism of collections may find guidance in research conducted by Pérez, Cuadrado, and Cervera to determine user attitudes toward book vandalism, with the ultimate goal of developing intervention measures. ${ }^{58}$ They found punishment (e.g., fines and charging replacement costs), surveillance, and exhibits featuring mutilated materials to be potential deterrents.

\section{Disaster Response}

Response to and preparation for disasters continues to be an integral part of conservation and preservation management. The field of disaster response includes risk management, insurance, security of collections and buildings, and protecting materials from damage because of fire, flood, and other natural or manmade disasters. ${ }^{59}$ Lunde and Smith, and Fleischer and Heppner note that risk management, disaster response and continuous operations planning, and security are all essential for protecting collections and institutions from theft, damage, and loss. ${ }^{60}$ These disaster plans include preventing loss of digital resources, access to computers and databases, and minimal or no loss of revenue stream. Preparing for loss, preventing damage, and responding appropriately in the face of all types of disasters is essential for the economic and intellectual well-being of cultural institutions.

While resources written for cultural institutions tend to focus on recovery of collections, the new emphasis of disaster response efforts is the financial viability of the institution or the enterprise as a whole. ${ }^{61}$ Plans for disaster response and prevention need to include decreasing risks during renovation projects and creating security in safe zones. Harris and DiMarco provide guidelines and basic policies for protecting patrons and staff during a crisis such as a bomb scare or a shooter. ${ }^{62}$ Harris and DiMarco define lockdown as "an emergency protocol to prevent people or information escaping." ${ }^{\prime 3}$ How does one control the panic and protect individuals? Planning for these situations is the key to a safe outcome. At the same time, institutions must consider the safety of buildings and collections during renovation. Again this requires planning, vigilance, and constant communication to prevent theft, fire, and water damage by inattentive construction workers, while minimizing the potential for injury and fluctuations in the environment in renovated areas. ${ }^{64}$ Oehlerts points out the critical need for better inventorying practices for collections. ${ }^{65}$ As she notes, "A major component of library risk management is being able to precisely identify what you own.,"66

\section{Preservation Planning and Programs}

Preservation planning must include a thorough assessment of risk to collections; these activities are particularly important 
for assessing the value of collection to provide appropriate insurance coverage. Galbraith and Seago report on the development of a survey instrument by insurer AXA Art that may be used to determine risk in the areas such as security, fire detection and suppression, inventory control, and emergency planning. ${ }^{67}$ Bülow reports on a risk assessment to determine priorities in the area of preservation and reduce risk where financially feasible conducted by the National Archives of the United Kingdom. ${ }^{68}$ The survey determined high risk to collections because of uncontrolled storage conditions, poor storage and retrieval practices, and careless handling during digitization and microfilming projects; actions were taken immediately to resolve these problems.

\section{Security}

Using the word security in the broadest sense, failure to secure collections risks the loss of documentary heritage, collective memory, and intellectual property. In a special issue of Library and Archival Security devoted to security concerns in the archival environment, Cox and colleagues set the stage for discussing issues of security for collections, particularly archival materials. ${ }^{69}$ They note that security must be considered from two perspectives; physical security of collections to prevent theft and mutilation; and accountability and ethics. Accountability is defined as making certain all materials are present, arranged to be findable, and accessible to the public.

Neff expands on the study by Cox and colleagues by highlighting forgeries of materials in cultural institutions. ${ }^{70}$ In this case, forgeries include altered documents and dates, and falsified provenance. These types of forgery call into question the authenticity of the materials and the reputation of the curators. Griffiths and Krol focus on preventing insider theft. ${ }^{71}$ They observe that thinking that staff members are more honest than researchers is naive and stress that one must be ever vigilant to prevent loss and publicize thefts when they happen.

\section{From Preservation to Curation: The Lifecycle of Digital Materials}

In the last decade, many new sources on digital preservation and curation research have been established and others have expanded their coverage of digital preservation issues. Journals that have become essential reading for preservation professionals interested in these areas include Ariadne, D-Lib Magazine, Information Standards Quarterly, The International Journal of Digital Curation, and the Journal of Digital Information. Furthermore, many established journals have published special issues on digital preservation, such as Library Hi Tech, Library Quarterly, and Library Trends.
In addition to literature found in journals, research reports from the following organizations are often the first sources for information on groundbreaking projects in digitization, digital preservation, and digital curation.

In the United States:

- Association of Research Libraries (ARL)

- Council on Library and Information Resources (CLIR)

- Educopia Institute

- OCLC Research

In the United Kingdom:

- Digital Curation Centre (DCC)

- Joint Information Systems Committee (JISC)

- Digital Preservation Coalition (DPC)

\section{Definitions of Digital Preservation and Digital Curation}

In the last decade, the areas of digital preservation and digital curation have emerged as new specialties for information professionals, as librarians, archivists, and curators have increased responsibilities to care for the products of digitization activities and born-digital materials. In 2007, the Preservation and Reformatting Section of the Association for Library Collections and Technical Services (ALCTS) drafted short, medium, and long definitions of digital preservation; the medium-length definition states, "Digital preservation combines policies, strategies and actions to ensure access to reformatted and born digital content regardless of the challenges of media failure and technological change. The goal of digital preservation is the accurate rendering of authenticated content over time." ${ }^{, 72}$ This definition reflects the changing understanding of what the phrase "digital preservation" connotes. Whereas it was once synonymous with digitization, the term now reflects a much larger set of responsibilities beyond reformatting activities.

Digital curation has an even greater scope than digital preservation. While it includes many activities that can be characterized as preservation-related, it encompasses all aspects of the lifecycle of digital objects. The DCC has defined digital curation as "maintaining, preserving, and adding value to digital research data throughout its lifecycle." ${ }^{73}$ Curation has a particular focus on the importance of data reuse by communities of practice, a function that is particularly important for the scientific disciplines but which also has significance for many other fields.

\section{Digital Curation and the Lifecycle Model}

Digital curation encompasses tasks such as creation, appraisal, ingest, various preservation actions, storage, transformation of data and objects into new objects, disposal, 
reappraisal, and migration. To represent this concept of curation, the DCC developed a model to illustrate the relationships between the different processes and activities. ${ }^{74}$

The DCC Lifecycle Model may be seen as complementary to the Open Archival Information System (OAIS) model, which was first developed by the Consultative Committee for Space Data Systems of the National Aeronautics and Space Administration (NASA) and later adopted as an international standard for archiving information (ISO 14721:2003). The OAIS model aims to establish the requirements for an archive "to provide permanent, or indefinite long-term, preservation of digital information." 75 Dryden notes that the OAIS model is "a conceptual framework for systems design, not a blueprint," and that "different implementation strategies are possible within the framework."

Both the OAIS and the DCC models are applicable to all types of information, not just scientific data, and have been widely adopted by institutions in the cultural heritage community. Similarly, curation is not a concept that is specific to the work accomplished by a particular discipline or industry, but may be applied to information management as it is practiced in any organizational environment. As Harvey points out, the DCC Curation Lifecycle Model "was not designed for any specific digital curation operation or for application to any particular discipline. It can be applied in a wide range of digital curation contexts, including institutional repositories, digital archives, and electronic records management." 77 He notes that it is particularly valuable because it conveys the critical knowledge that successful preservation and reuse of archived data rely on good data design and capture of essential information about data from the point of creation. Constantopoulos and colleagues, and Dubin and colleagues have suggested refinements to the DCC Model that would incorporate additional information about usage and semantic knowledge about curated objects. ${ }^{78}$

\section{Creation and Use Patterns of Digital Material}

The DCC Lifecycle model also is a helpful starting point in considering the progress that has been made in developing infrastructure for digital curation and designing tools to help achieve preservation and access goals. In the last few years, practitioners and researchers have focused significant attention on studying communities of practice and meeting technical challenges to support curation functions. In particular, the field has concentrated on the earlier part of the lifecycle by developing methods to study how users create, use, and reuse data. In a series of case studies, researchers from the JISC in the United Kingdom have examined a number of key communities in the hard sciences, social sciences, and engineering to identify patterns of data creation, use, reuse, and archiving through the Disciplinary Approaches to Sharing, Curation, Re-use and Preservation (SCARP) project. $^{79}$ The purpose of the studies was to achieve "a better understanding of the diversity of researchers' data practices, and of their needs and expectations of support for data management and preservation." $\$ 0$ Similar studies in the arts and humanities areas have been undertaken or suggested, one example being the work accomplished by Benardou and colleagues for the Digital Research Infrastructure for the Arts and Humanities project, which aims to provide "the foundations (strategic, financial, legal, technological and conceptual) for the timely design and construction of the digital infrastructure requisite for scholarly research in the arts, humanities and cultural heritage in Europe." ${ }^{81}$ Witt and colleagues offer guidance about how one might create data curation profiles, instruments that could be used to identify particular data forms that might be curated by an institution to support the work of particular domains or communities of practice. ${ }^{82}$

\section{Technical Challenges of Digital Preservation}

The technical challenges of preserving digital materials are numerous and daunting. At every point in the curation lifecycle, preservation managers must perform certain actions on digital objects and maintain information about those actions. Each phase in a digital object's lifecycle involves a sequence of events. Harvey notes that the seemingly simple act of ingesting an object into a repository involves many steps, including, but not limited to, identifying file formats, generating fixity values (such as a hash digest or checksum), checking for viruses, generating metadata records for objects, converting files to a preservation-ready format (often referred to as normalization), and assigning persistent identifiers to files. ${ }^{83}$

At the point when the information package, containing the object and associated metadata, is submitted to the archive, throughout its life in long-term storage, and when that object is retrieved from the archive for delivery to data requestors, events and changes must be documented to maintain the provenance of the material. To accomplish these objectives, digital curators require technical solutions integrated into all stages of the data lifecycle. According to Harvey, "The ideal is to collect metadata by automated processes close to the point of data creation so that the need for costly human input is minimized." $" 4$

\section{Development and Evaluation of Digital Preservation Tools}

The digital preservation communities in North America, Europe, Australia, and New Zealand have invested significant effort in the development of digital preservation tools and repository infrastructures. The complexity of managing objects in every phase of their lifecycle means that the possibility of any one institution or even consortia of institutions 
building a repository environment that satisfies archiving requirements for every community of users is unlikely. Thus, given the enormity of challenge, this process of development has been highly collaborative. Many tools have been developed using open source development processes and have been distributed widely, available to anyone who wishes to download the source code. Examples of tools that have been made available to the public include the Library of Congress' Transfer Tools, the JSTOR/Harvard Object Validation Environment (JHOVE/JHOVE2), the National Library of New Zealand's Metadata Extraction Tool, and the National Archives of Australia's Digital Preservation Software Platform. ${ }^{85}$ The literature contains several helpful articles published by developers or early implementers that explain the functionality of tools or report on tests of tools in experimental or production environments. Ashenfelder and colleagues explain how the Library of Congress Transfer Tools facilitate network transfer of digital files from data creators to the repository. ${ }^{86}$ The toolset uses the BagIt specification, which consists of a virtual container accompanied by a manifest that helps to maintain the original organization of the files and also acts as a seal of authenticity that the files have not been altered in any way during the transfer process. Abrams and colleagues report on the development of JHOVE2, a format characterization tool that allows repositories to identify and validate file formats, and also extract key file characteristics (also known as significant properties). ${ }^{87}$ These capabilities help repositories gather critical information necessary in preservation planning and developing action plans. While the development of individual tools to assist in particular activities such as format validation and integrity checks has been very helpful, Hswe and colleagues stress that digital preservation environments require the integration of tools into larger repository structures and workflows. ${ }^{88}$

\section{Types of Preservation Repositories}

Caplan categorizes digital preservation repository implementation into three models: distributed replication, repository and toolkit, and formal OAIS. ${ }^{89}$ The first model, distributed replication, is typified by the Lots of Copies Keep Stuff Safe (LOCKSS) repository. In the LOCKSS system, a group of institutions creates a private network running interconnected LOCKSS boxes. These boxes maintain the integrity of digital materials stored on each computer through continuous polling among its members, which ensures that copies remain unchanged and that corrupted files are replaced with new copies when necessary. Caplan points out that this is essentially for a "dark archive"LOCKSS-style repositories were not designed to serve users materials, but to be an archive of last resort.

The second model, repository and toolkit, is common in
Europe and Australia. In this scenario, institutions often run an institutional repository system such as DSpace or ePrints into which digital preservation tools can be integrated. It adds preservation functionality to systems that may not have initially been designed primarily to support preservation and curation activities. The European Preservation and Long-Term Access to Our Cultural and Scientific Heritage (PLANETS) project is an example of this model.

The last model, formal OAIS repository, is more common in North America. It is designed specifically to support preservation functions, from ingest to long-term storage to dissemination (e.g., the OAIS model), While tools are integrated into these systems at the time of initial distribution, implementers cannot add new tools as they are developed or swap out old tools for new ones (as can be done in the repository and toolkit model). The State of Florida's Dark Archive in the Sunshine State (DAITSS) system, Portico (the digital preservation service offered by ITHAKA), and various institutional repositories of national libraries, such as Koninklijke Bibliotheek, the national library of the Netherlands, follow this model of development.

As repository design becomes more sophisticated, the micro-services model, where functionality is no longer interdependent with repository architecture, has appeared. Abrams and colleagues describe the approach, pioneered by the California Digital Library, as

devolving function into a set of granular, independent, but interoperable micro-services. Since each of these services is small and self-contained, they are more easily deployed, maintained, and enhanced; at the same time, complex curation function can emerge from the strategic combination of atomistic services. ${ }^{90}$

\section{Collaboration: Registry Services and Preservation Workflows}

Developing tools, services, and repositories to support digital preservation and curation work is a highly collaborative process. Two areas benefitting from these joint efforts are data and registry services, and preservation workflows.

Data and registry services gather information from a variety of sources and make it freely available to the preservation and curation communities. Examples of registry services include format information registries such as PRONOM and the Global Digital Formats Registry (to be merged into the Unified Digital Formats Registry and the e-Journals Preservation Registry Service) ${ }^{91}$

Institutions work together, often within consortial arrangements, to develop effective preservation workflows that will benefit the field as a whole. Many are proof-ofconcept exemplars that eventually may be incorporated into 
production environments. The PLANETS project has created a series of tools and services that can be used together in a test bed environment to analyze the effectiveness of various preservation strategies. ${ }^{92}$ The Personal Digital Archives and Library System (PeDALS) Project, which works within the LOCKSS model, seeks to "articulate a curatorial rationale that describes an automated workflow for processing collections of digital archives and publications." ${ }^{.93}$ Developers have created a workflow for the Controlled LOCKSS (CLOCKSS) system, to make material openly available after "trigger events." ${ }^{94}$ Other institutions reported on the development of workflow procedures and processes in the literature, including University of Oregon, in the area of electronic records management, and digital imaging at the University of Maryland..$^{95}$ These reports should be seen as illustrative of the types of workflows under development.

\section{Metadata Standards for Preservation}

The last decade has seen significant progress in the development of metadata for digital preservation. PREservation Metadata: Implementation Strategies (PREMIS), first released in 2005 (version 1) and revised in 2008 (version 2), provides librarians and archivists with the means for documenting information about the digital object, its required technical environment, and its provenance, while also empowering professionals with the ability to record details of future preservation activities. ${ }^{96}$ PREMIS has become a key metadata standard for the digital preservation community and, according to Vermaaten, is often integrated with other standards such as METS (the Metadata Encoding Transmission Standard). ${ }^{97}$

Other notable developments in preservation-related metadata standards include the Repository eXchange (RXP) protocol, domain and format-specific metadata standards, and standards for embedding metadata in word processing documents. According to Caplan, Kehoe, and Pawletko, the Repository eXchange Package (RXP) protocol—a joint development by the Florida Center for Library Automation, Cornell University, and New York University-will facilitate transfer of materials between institutional repositories, solving problems of incompatibility between Archival Information Packages (AIPs) generated by different repository systems. ${ }^{98}$

Metadata standards for particular domains, formats, and applications also are under development. Otto reports on the current status of AES-X098B, the Audio Engineering Society's audio object technical metadata standard for audio objects. ${ }^{99}$ Otto identifies the critical need for a robust technical metadata standard for audiovisual material and explores the potential application of AES-X098B for other types of complex multimedia, particularly moving images.

Naumann, Keitel, and Lang describe the development of a metadata schema for the Landesarchiv (State Archive) of Baden-Württemberg to handle information about heterogeneous digital archives. ${ }^{100}$ This standard aims to manage metadata from a number of different formats and genres of information, including statistical primary data; data from records management systems (RMS) and geographical information systems (GIS); office files; digitized papers, parchment, maps and photographs; system manuals; and data descriptions. Some older databases also include paper documentation, which can result in hybrid objects (i.e., a database with paper documentation). The metadata schema includes descriptive, technical, structural, and fixity elements.

In the area of scientific metadata, Matthews and colleagues introduce the Core Scientific Metadata Model (CSMD), which was developed by the Science and Technology Facilities Council of the United Kingdom. ${ }^{101}$ The CSMD model aims to "capture high level information about scientific studies and the data that they produce," including information about the studies themselves and the people involved with them; annotations and indexing terms; publications associated with the studies; datasets, data files, and associated technical metadata; parameters of the studies, such as measurements used in samples and environments where data was collected; and authorization, indicating who may access and use study data. ${ }^{102}$

To assist curators in documenting files gathered through web harvesting activities, the International Internet Preservation Consortium (IIPC) has issued guidelines for implementing the Web ARChive (WARC) file format, which is becoming the accepted metadata standard for web archive files. ${ }^{103}$ This document gives direction on best practices in file naming, record identification, recording of information about harvesting and processing actions, and converting ARC files to the WARC format.

Last, Sefton and colleagues report on techniques being used to embed metadata and inline semantics in word processing documents to support access as well as preservation activities. ${ }^{104}$ These approaches are format-agnostic; the aim is for the technology to be usable in proprietary and open source environments (e.g., in Microsoft Word as well as in OpenOffice, with the Open Document Format (ODF) being the primary file format used). Semantic objects considered as candidates for embedding in documents include semantic terms, such as indexing terms or provenance information, block elements such as sidebars in technical manuals, and data visualizations.

\section{Preserving Authenticity of Digital Objects}

One of the thorniest problems that digital preservationists face in creating and maintaining trusted digital repositories is how to guarantee the authenticity of digital materials over time. Archivists employ a number of methods to ensure 
the authenticity of digital objects, including following best practices in data security and backups, metadata generation to track all activities in all phases of the objects' lifecycle, and the use of digital signatures and digital certificates for transfer of materials in and out of the digital archive. ${ }^{105}$ Because digital objects and records can be subjected to many transformations over their lifecycle as archivists work to keep them accessible to users, preservation activities and information about provenance must be well-documented.

Another concept closely related to authenticity is the idea that a digital object possesses features particular to its format, document genre, and presentation that must be retained when the object is transformed for purposes of preservation (i.e., reformatted or migrated). ${ }^{106}$ As Harvey notes,

To keep digital objects, make them accessible, and be able to process and use them over time, we need to know precisely what it is we want to keep. More specifically, we need to know which of the properties or characteristics of the digital object we must maintain over time. These properties or characteristics are known as significant properties. ${ }^{107}$

While the concept of significant properties is valuable for preservation professionals who study the nature of digital objects and try to build systems to maintain authentic objects over time, significant properties cannot be defined absolutely and universally. What makes an acceptable copy is often in the eye of the beholder-different communities will have varying requirements for what constitutes the critical features of a document. ${ }^{108}$

\section{Risk Management and Preservation Planning for Digital Preservation}

Risk management for digital collections constitutes a key part of the planning process for digital preservation programs. ${ }^{109}$ Several risk management frameworks and tools have recently become available that will be valuable aids in preservation and curation work.

The concept of the trusted digital repository (TDR) has become a central trope of the digital preservation discourse, as the field strives to build reliable systems and structures for long-term storage of digital materials. In 2007, the Center for Research Libraries and OCLC published the Trustworthy Repositories Audit \& Certification: Criteria and Checklist, known as TRAC, for TDRs. ${ }^{110}$ Several institutions, such as Cornell University and Columbia University, have used these criteria to assess risks to materials stored in digital repositories. ${ }^{111}$ TRAC is currently under review to become an International Standards Organization (ISO) standard. ${ }^{112}$

Two web-based toolkits that hold promise for assisting professionals in preservation planning are the Digital
Repository Audit Method Based on Risk Assessment (DRAMBORA), developed by the Digital Curation Centre and Digital Preservation Europe, and Plato, developed by the PLANETS project. DRAMBORA "presents a methodology for self-assessment, encouraging organisations to establish a comprehensive self-awareness of their objectives, activities and assets before identifying, assessing and managing the risks implicit within their organisation." 113 The developers of DRAMBORA used the TRAC criteria in creating their assessment framework. Case studies looking at how DRAMBORA has been implemented in the field are beginning to appear in the literature, such as that written by Innocenti and Vullo of the University of Glasgow. ${ }^{114}$ Barateiros and colleagues have suggested that the risk management approach, primarily used at this stage to develop assessment criteria for digital repositories (i.e., TRAC), also should be integrated into the design process. ${ }^{115}$

Preservation planning is an essential part of risk management. While preservation administrators have had access to tools to create preservation plans for physical materials for many years (e.g., needs assessment surveys such as CALIPR, and disaster planning tools such as dPlan), they often were inadequate to plan for digital preservation requirements. ${ }^{116}$ The preservation community now has a planning tool that is designed specifically for digital materials. Plato is described as a "decision support tool that implements a solid preservation planning process and integrates services for content characterisation, preservation action and automatic object comparison in a service-oriented architecture to provide maximum support for preservation planning endeavours." 117 While Plato was not designed to accomplish collection-wide needs assessment, it does allow institutions to compare the effectiveness of different preservation strategies to make informed choices about how best to preserve digital materials, given the constraints of a particular institution's resources and the needs of its designated community of users. ${ }^{118}$

\section{Economic Sustainability}

As part of an overall risk management policy, institutions also must consider the economic sustainability of digital preservation and curation programs. While short-term digital projects often have been well-funded by granting agencies such as the National Science Foundation, the National Endowments, and the Institute for Museum and Library Services in the United States, and by governmental agencies in Canada, Europe, and Australia, long-term digital preservation programs have had significant difficulty in sustainability, which includes developing a business case, establishing a business model, and measuring costs. ${ }^{119}$ The Blue Ribbon Task Force on Sustainable Digital Preservation and Access recently studied the sustainability challenge, 
with a focus on analyzing the reasons for market failure in developing feasible digital preservation solutions. ${ }^{120}$ The task force report issued in 2010 created action agendas for the key players in the digital preservation field, including data creators, owners, repositories, and users to begin to address sustainability concerns in the United States. ITHAKA and PLANETS also studied the problem of economic sustainability in the United Kingdom and Europe. ITHAKA gathered case studies of how U.K. and European organizations are generating revenue and minimizing costs for digital preservation programs, finding that most programs rely on a mix of revenue generated from subscription, licensing, and consulting activities as well as host institution financial support-few programs are completely self-sufficient at this stage. ${ }^{121}$ The recent white paper from PLANETS on the emerging market for digital preservation tools and services summarizes data from interviews with eighteen suppliers and vendors in the digital preservation arena. ${ }^{122}$ The study found that legal obligation to preserve material, either for business requirements or to fulfill an organization's mission, is the key driver for digital preservation needs and activities now. Uncertainty about costs and potential economic benefits make constructing a good business model for digital preservation difficult, however.

\section{The New Preservationist}

The preservation field has seen several respected graduate programs experience cutbacks or even closure. The recent demise of conservation and preservation administration programs at the University of Texas and elsewhere suggest that the preservation and conservation professions are in a period of retrenchment and transition. ${ }^{123}$

In reflecting on these changes, one has a strong sense that further differentiation and stratification among practitioners and researchers in the preservation arena is likely, particularly as more and more material to be preserved originates in digital form rather than being the product of a reformatting action. As digital material becomes ever more central to collections and endeavors, concern grows about how best to preserve those digital materials and who will take on the responsibility of long-term care. The recognition that the next generation of librarians and archivists must be equipped to manage all types of collections-in various analog and digital formats - in all manner of institutions, has brought about numerous changes in how preservationists and conservators are being educated. In the last decade, several programs focusing on media preservation, digital preservation, and digital curation have been established to meet these critical challenges for safeguarding collections and providing increased access to this material. The recent literature suggests that the preservationists of tomorrow may possess a very different skill set from the generations that came before them. ${ }^{124}$

Educational programs tend to emphasize the differences in the skills required of physical preservation and digital preservation professionals, rather than stressing a holistic approach, which would equip students to understand both traditions and knowledge bases. While arguing that a single educational program could equip students with collections conservation hand skills and the technical knowledge of information systems and programming required to build preservation-ready institutional repositories is difficult, any program that aims to educate either conservators or digital curators must emphasize the importance of developing managerial expertise and economic savvy. Additionally, the convergence of libraries, archives, and museums suggests that the field will need professionals who are boundarycrossers as well as specialists. ${ }^{125}$

In the conservation field, practitioners have raised concerns that training based in academic programs, rather than conservation laboratories and in practice, will lead to conservators without sufficient preparation to actually perform the work required. Von Imhoff worries that the conservator emerging from current academic conservation programs lacks the hand skills required for basic repair and restoration tasks, despite an increasing knowledge of historical context and the science of conservation. ${ }^{126}$

Meanwhile, programs in digital preservation and archiving have been focusing on developing laboratory environments that will allow students to experiment with new software tools and repository environments developed by practitioners in conjunction with programmers. The focus for these new laboratories is an increased emphasis on providing experiential learning opportunities beyond what has been available previously. Bastian and colleagues report that a curriculum laboratory in development at Simmons College provides students with learning modules offering scenarios they may encounter in practice and that give them tools and guidance to develop problem-solving skills. ${ }^{127}$ The educational content is being developed and tested in collaboration with several practitioner institutions and educational programs.

\section{Continuing Education}

While digital preservation and curation programs and initiatives - such as NEDCC's School for Scanning and Digital Directions conferences, LYRASIS programs, and the University of North Carolina's Digital Curation Curriculum (DigCCurr) II project-have been established at several information schools across the country, Molinaro expresses concern that the knowledge and skills in these areas have not fully penetrated to the local level of practice despite such programs. ${ }^{128}$ Local institutions, which lack access to basic information about best practices of digitization and digital 
preservation, may make poor decisions when converting materials to digital form or when planning for storage or migration, leading to collections that have a poor chance of long-term survival. Molinaro states,

If we have any hope to preserve the digital record of our lives and collections there must be a coordinated effort that takes advantage of the years of work that has been put into the development of the practices that will provide the best shot at sustainability. People at the local level must be encouraged and supported to represent their collections and communities in a digital form that has a very good chance to persist over time. We must leverage the expertise that exists and make it easy for people at the local level to know what to do. ${ }^{129}$

One project that targets the need for information and expertise at the local level is the Digital Preservation Outreach and Education program, which is a new initiative of the Library of Congress National Digital Information Infrastructure and Preservation Program (NDIIPP). ${ }^{130}$

\section{Conclusion}

The literature reviewed for this paper reveals a preservation field grappling with tremendous change. The authors reviewed and discussed literature in five areas: the tensions and challenges for preservation administrators as libraries embrace digital resources, mass digitization and its effects on the longevity of collections, increased awareness of risk management and disaster response, the need for digital preservation and curation, and the changing focus on preservation education in the digital age. Libraries are in the process of reinventing themselves and preservation practice will inevitably follow suit. As libraries become collaborative workspaces, making more room for users and shifting print collections and preservation activities offsite, preservation professionals will engage less in custodial activities and more in the work of making long-lasting, accessible digital products through the processes of digitization and digital curation. The future of the preservation field lays in effective implementation of digital technologies for collection building, strong leadership in standards and best practices development, and careful management of resources to continue to care for print collections and give increased attention to those materials that most need our attention (audiovisual and born-digital materials). While preservation professionals' responsibilities to care for the record of human activities continues to grow apace with the development of information technologies, those same technologies offer them opportunities to increase access to materials in ways unimaginable in decades past. As Conway writes, "It is the end of preservation as we know it," but the authors believe that the profession has many reasons to be optimistic about the future. ${ }^{131}$

\section{References and Notes}

1. JeanAnn Croft, "The Preservation Evolution: A Review of Preservation Literature, 1999-2001," Library Resources d Technical Services 47, no. 2 (2003): 59-70.

2. Nicholson Baker, Double Fold: Libraries and the Assault on Paper (New York: Random House, 2001).

3. In this paper, the adjective "analog" may be defined thus: "of signals or data: represented by a continuously variable physical quantity, such as voltage, spatial position, etc." This definition contrasts with that of digital used as an adjective: "of signals, information, or data: represented by a series of discrete values (commonly the numbers 0 and 1 ), typically for electronic storage or processing." Both definitions are taken from the Oxford English Dictionary, online edition, s.v. "Analog" and "Digital," www.oed.com (accessed September 14, 2011).

4. Kathleen Arthurs et al., Recognizing Digitization as a Preservation Reformatting Method (Washington, D.C.: ARL, 2004), www.arl.org/bm doc/digi_preserv.pdf (accessed June 19, 2011).

5. Electronic discussion lists included those established for the Association of Library Collections and Technical Services Preservation Administrators' Interest Group (padg@ala.org) and Digital Preservation Interest Group (digipres@ala.org), and the Joint Information Systems Committee (digital-preservation@jiscmail.ac.uk).

6. Karen F. Gracy and Miriam B. Kahn, with the assistance of Sarah Baker, Heather Flynn, and Nicole Yoder, "Preservation in the Digital Age: A Review of Preservation Literature, 2009-10: Supplementary Bibliography," http://alcts.ala.org/ lrts/digitalage_bib1111.pdf (accessed Nov. 15, 2011).

7. Chris Rusbridge, "Towards the Hybrid Library," D-Lib Magazine 4, no. 7/8 (1998), www.dlib.org/dlib/july98/ rusbridge/07rusbridge.html (accessed June 19, 2011).

8. See, for example, Adupa Sunil and K. Praveen Kumar, "Preservation of Library Materials: Problems and Perspective," DESIDOC Journal of Library \& Information Technology 29, no. 4 (2009): 37-40.

9. Richard Pearce-Moses, ed., A Glossary of Archival and Records Terminology (Chicago: SAA, 2005), www.archivists. org/glossary/term_details.asp?DefinitionKey=2704 (accessed Sept. 6, 2011).

10. Michael A. Arthur and Lee Dotson, "Bringing Preservation to the Forefront: Preservation Initiatives at the University of Central Florida Libraries," Florida Libraries 52, no. 2 (2009): $16-18$.

11. CeROArt, http://ceroart.revues.org (accessed Aug. 1, 2011); E-Conservation Magazine, www.e-conservationline.com (accessed Aug. 1, 2011); E-Preservation Science, www.morana-rtd.com/e-preservationscience (accessed Aug. 1, 2011).

12. Irene Brückle, "Bleaching Paper in Conservation: DecisionMaking Parameters," Restaurator 30, no. 4 (2009): 323. 
13. Bernhard Fischer, "Goethe- and Schiller-Archive, Weimar: Guidelines for the Preservation and Conservation," Restaurator 30, no. 1-2 (2009): 93.

14. Jozef Hanus et al., "Survey of Historical Manuscripts Written with Iron Gall Inks in the Slovak Republic," Restaurator 30, no. 3 (2009): 165-80; Jiazhen Liu and Jingxuan Wang, "Main Factors Affecting the Preservation of Chinese Paper Documents: A Review and Recommendations," IFLA Journal 36, no. 3 (2010): 227-34.

15. Mark Allen, "The Conservation of the Flintshire and Denbighshire Enclosure Awards Including the Treatment of MultiMembrane Parchment Documents," Journal of the Society of Archivists 31, no. 1 (2010): 63-72; Rachel Clarke, "Preservation of Mixed-Format Archival Collections: A Case Study of the Ann Getty Fashion Collection at the Fashion Institute of Design and Merchandising," American Archivist 72, no. 1 (2009): 185-96; Rhea DeStefano, "Treatment of the J. O. Halliwell-Phillipps Collection of Albums with Shakespearean Rarities at the Folger Shakespeare Library," Restaurator 31, no. 2 (2010): 75-76.

16. DeStefano, "Treatment of the J. O. Halliwell-Phillipps Collection."

17. Salvador Muñoz-Viñas, "The Impact of Conservation Pressure-Flattening on the Dimensions of Machine-Made Paper," Restaurator 30, no. 3 (2009): 181-98; Irene Brückle, "Bleaching in Paper Production Versus Conservation," Restaurator 30, no. 4 (2009): 280-93; Masazumi Seki et al., "A New Technique for Strengthening Book Papers with Cellulose Derivatives. Part 2: Effect of Cellulose Derivatives on Different Types of Paper," Restaurator 31, no. 2 (2010): 126-41; Heidi Lennig, "Solvent Gels for Removing Aged Pressure-Sensitive Tape from Paper," Restaurator 31, no. 2 (2010): 92-105; Gerhard Banik, "Scientific Conservation: Transfer of Scientific Research on Ink Corrosion to Conservation Practice-Does It Take Place?," Restaurator 30, no. 1-2 (2009): 131-46; John W. Baty et al., "Deacidification for the Conservation and Preservation of Paper-Based Works: A Review," BioResources 5, no. 3 (2010), http://ojs.cnr.ncsu.edu/index.php/BioRes/ article/viewFile/BioRes_05_3_a_Baty_MMHJ_Deacidification_Paper_Review/806 (accessed June 20, 2011); Eva Hummert and Andrea Pataki-Hundt, "Ultrasonic Cleaning of Mud Encrustations from Flood Damaged Woodcuts," Restaurator 31, no. 1 (2010): 65-74.

18. Whitney Baker and Liz Dube, "Identifying Standard Practices in Research Library Book Conservation," Library Resources \& Technical Services 54, no. 1 (2010): 21-39.

19. Don Etherington, Bookbinding and Conservation: A SixtyYear Odyssey of Art and Craft (New Castle, Del.: Oak Knoll, 2010); Pamela Train Leutz, The Thread That Binds: Interviews with Private Practice Bookbinders (New Castle, Del.: Oak Knoll, 2010); Jen Lindsay, Fine Bookbinding: A Technical Guide (London: British Library, 2009); Julia Miller, Books Will Speak Plain: A Handbook for Identifying and Describing Historical Bindings (Ann Arbor, Mich.: Legacy, 2010).

20. Clarke, "Preservation of Mixed-Format Archival Collections"; Somnath Das, "Preservation of Newspapers," DESIDOC Journal of Library \& Information Technology 29, no. 1 (2009): 72-75; Damir Hasenay and Maja Krtali , "Preservation of
Newspapers: Theoretical Approaches and Practical Achievements," Journal of Librarianship \& Information Science 42, no. 4 (2010): 245-55.

21. Laura Robinson, "The Evolution of Newspaper Digitization at the Washington State Library," Microform \& Imaging Review 39, no. 1 (2010): 24-27; Kopana Terry, "The Digitization of Historic Newspapers on Microfilm: The Kentucky Experience," Microform \& Imaging Review 38, no. 2 (2009): 54-63.

22. Paul Conway, "Preservation in the Age of Google: Digitization, Digital Preservation, and Dilemmas," Library Quarterly 80, no. 1 (2010): 65.

23. Jill Hurst-Wahl, "Digitization: How Many Best Practices, Guidelines, and Standards Do We Need?," Information Standards Quarterly 21, no. 4 (2009): 22-24.

24. Anna E. Bülow, Jess Ahmon, and with contributions from Ross Spencer, Preparing Collections for Digitization (London: Facet, 2011).

25. The Institute for Museum and Library Services recently funded a research proposal made by New York University's Moving Image and Archiving Program to study the need for moving image specialists in libraries. Moving Image and Archiving Program, New York University, "Moving Image Specialists in Libraries," http://blogs.nyu.edu/tisch/preservation/research/libraries/about.html (accessed Sept. 14, 2011).

26. Andrea Imre and Elizabeth J. Cox, "Are We on the Right Track? Issues with LP Record Collections in U.S. Academic Libraries," Notes 65, no. 3 (2009): 475-86.

27. Heather Heckman, "Burn after Viewing, or, Fire in the Vaults: Nitrate Decomposition and Combustibility," American Archivist 73, no. 2 (2010): 483-506; Andy Kraushaar, "Saving Shattered Images," Microform \& Imaging Review 38, no. 3 (2009): 107-8; Sarah Norris, "Effects of Desiccation on Degraded Binder Extraction in Magnetic Audio Tape," ARSC Journal 41, no. 2 (2010): 183-99.

28. Debra Hess Norris and Jennifer Jae Gutierrez, eds., Issues in the Conservation of Photographs (Los Angeles: Getty Conservation Institute, 2010)

29. Bertrand Lavédrine, Photographs of the Past: Process and Preservation (Los Angeles: Getty Conservation Institute, 2009).

30. Gary A. Galo, "The Columbia LP Equalization Curve," ARSC Journal 40, no. 1 (2009): 40-58; Lance Christensen, "From Discovery to Recovery: The Electronic Transfer of the J. R. Walker Native American Cylinder Record Collection," ARSC Journal 40, no. 1 (2009): 21-39; Christopher Bird, "Europe Ain't Gonna See This Scene! Working with Variant Versions in Photoplay Productions' Restoration of the Cat and the Canary," The Moving Image 9, no. 2 (2009): 149-63; Gary A. Galo, "Phase Equalization and Its Importance in the Reproduction of Disc Records," ARSC Journal 41, no. 1 (2010): 83-96; Ralph Sargent, "Legacy Analog Optical Recordings: Then and Now," AMIA Tech Review 2 (2010), www.amia conference.com/techrev/V10_02/sargent.htm (accessed June 14, 2011); Ralph Sargent and Al Sturm, "Type A and the Everly Brothers Show," AMIA Tech Review 1 (2010), www .amiaconference.com/techrev/V01_01/sturm_sargent.htm (accessed June 14, 2011); Bob Heiber, “Tommy, Can You 
Hear Me? The Quintaphonic Restoration of a 'One Hit Wonder," AMIA Tech Review 2 (2010), www.amiaconference. com/techrev/V10_02/heiber.htm (accessed June 14, 2011).

31. Sean Patrick Kilcoyne, "You Shouldn't Have Been That Sentimental: Film Restoration Ethics in Hitchcock's Vertigo," Journal of Information Ethics 19, no. 1 (2010): 57-73; Lindsay Kistler Mattock, "From Film Restoration to Digital Emulation: The Archival Code of Ethics in the Age of Digital Reproduction," Journal of Information Ethics 19, no. 1 (2010): 74-85; Nina Rao, "Representation and Ethics in Moving Image Archives," The Moving Image 10, no. 2 (2010): 104-23.

32. Clarke, "Preservation of Mixed-Format Archival Collections," 196

33. Mark A. Greene and Dennis Meissner, "More Product, Less Process: Revamping Traditional Archival Processing," American Archivist 68, no. 2 (2005): 208-63; Carl Van Ness, "Much Ado about Paper Clips: 'More Product, Less Process' and the Modern Manuscript Repository," American Archivist 73, no. 1 (2010): 129-45; Robert S. Cox, "Maximal Processing, or, Archivist on a Pale Horse," Journal of Archival Organization 8, no. 2 (2010): 134-48.

34. Peggy Johnson, "From the Editor's Desk," Technicalities 29, no. 4 (2009): 2-4; Robert H. Kieft and Bernard F. Reilly, "Regional and National Cooperation on Legacy Print Collections," Collaborative Librarianship 1, no. 3 (2009): 106-8, www.collaborativelibrarianship.org (accessed June 15, 2011); Robert H. Kieft and Lizanne Payne, "A Nation-Wide Planning Framework for Large-Scale Collaboration on Legacy Print Monograph Collections," Collaborative Librarianship 2, no. 4 (2010): 229-33, http://collaborativelibrarianship.org/ index.php/jocl/article/view/119/77 (accessed June 15, 2011); Cathy Maskell, Jennifer Soutter, and Kristina Oldenburg, "Collaborative Print Repositories: A Case Study of Library Directors' Views," Journal of Academic Librarianship 36, no. 3 (2010): 242-49.

35. Constance Malpas, RLG Partnership Shared Print Collections Working Group: Shared Print Policy Review Report (Dublin, Ohio: OCLC Research, 2009), www.oclc.org/research/publications/library/2009/2009-03.pdf (accessed June 17, 2011).

36. Patricia A. Morris, "Preservation Needs of Children's Literature in Academic Libraries," portal: Libraries o the Academy 10, no. 1 (2010): 95-110.

37. Cathleen Martyniak, "When Preservation Moves Off Campus: Trends and Effective Practices in ARL Libraries," Library Resources of Technical Services 54, no. 4 (2010): 183-99.

38. Kacy L. Guill, "Arguing for Space in an User-Focused Environment," Library \& Archival Security 22, no. 2 (2009): $115-23$.

39. Conway, "Preservation in the Age of Google."

40. William C. Dougherty, "The Google Books Project: Will It Make Libraries Obsolete?” Journal of Academic Librarianship 36, no. 1 (2010): 86-89.

41. Oya Y. Rieger, Preservation in the Age of Large-Scale Digitization (Washington, D.C.: Council on Library and Information Resources, 2008), www.clir.org/pubs/reports/pub141/ pub141.pdf (accessed June 28, 2011), cited in Conway,
"Preservation in the Age of Google," 68.

42. Conway, "Preservation in the Age of Google."

43. Clifford A. Lynch, "Special Collections at the Cusp of the Digital Age: A Credo," Research Library Issues no. 267 (2009): 4

44. See, for example, Mitchell Whitelaw, "Visualising Archival Collections: The Visible Archive Project," Archives \& Manuscripts 37, no. 2 (2009): 22-40.

45. Allen C. Benson, "Killed Negatives: The Unseen Photographic Archives," Archivaria, no. 68 (2009): 1-37; Tom Evens and Laurence Hauttekeete, "Unlocking Audio: Towards an Online Repository of Spoken Word Collections in Flanders," D-Lib Magazine 15, no. 5/6 (2009), www.dlib.org/dlib/may09/ evens/05evens.html (accessed June 15, 2011).

46. Helen Shenton, "Virtual Reunification, Virtual Preservation, and Enhanced Conservation," Alexandria 21, no. 2 (2009): 33-45.

47. ARL Working Group on Special Collections, Special Collections in ARL Libraries: A Discussion Report from the ARL Working Group on Special Collections (Washington, D.C.: ARL, 2009): 19, www.arl.org/bm doc/scwg-report. pdf (accessed June 17, 2011); Anne R. Kenney, "The Collaborative Imperative: Special Collections in the Digital Age," Research Library Issues no. 267 (2009): 20-29.

48. George V. Landon, "Toward Digitizing All Forms of Documentation," D-Lib Magazine 15, no. 3/4 (2009), www.dlib. org/dlib/march09/landon/03landon.html (accessed June 15, 2011).

49. Gretchen Gueguen and Ann M. Hanlon, "A Collaborative Workflow for the Digitization of Unique Materials," Journal of Academic Librarianship 35, no. 5 (2009): 468-74; Oya Y. Rieger, "Enduring Access to Special Collections: Challenges and Opportunities for Large-Scale Digitization Initiatives," Rare Books \& Manuscripts 11, no. 1 (2010): 11-22.

50. Rieger, "Enduring Access to Special Collections," 13, 14.

51. All books published prior to 1923 fall into the public domain, as well as certain books published between 1923 and 1963 for which the original copyright expired and was not renewed. Note that copyright periods may be different for certain materials such as sound recordings, which were governed by state, not federal laws, for most of the twentieth century, and unpublished material. Cornell University maintains a handy chart for determining copyright status of material based on publication or creation date, which can be found at http:// copyright.cornell.edu/resources/publicdomain.cfm (accessed June 28, 2011). For an overview of the special case of sound recordings, see Tim Brooks, "Copyright and Historical Sound Recordings: Recent Efforts to Change U.S. Law," Notes 65, no. 3 (2009): 464-74.

52. Brian Lavoie and Lorcan Dempsey, "Beyond 1923: Characteristics of Potentially In-Copyright Print Books in Library Collections," D-Lib Magazine 15, no. 11/12 (2009), www.dlib. org/dlib/november09/lavoie/11lavoie.html (accessed June 15, 2011).

53. Dharma Akmon, "Only with Your Permission: How Rights Holders Respond (or Don't Respond) to Requests to Display Archival Materials Online," Archival Science 10, no. 1 (2010): 45-64. 
54. Maggie Dickson, "Due Diligence, Futile Effort: Copyright and the Digitization of the Thomas E. Watson Papers," American Archivist 73, no. 2 (2010): 626-36.

55. Jae D. Chang and Bryan Falk, "Experimental and Computer Simulation Approach to Investigating the Environmental Performance of a Rare Books Archive," E-Preservation Science Journal 6 (2009): 180-85, www.morana-rtd.com/epreservationscience/2009/Chang-01-06-2008.pdf (accessed June 15, 2011).

56. Ibid., 180.

57. Flavia Pinzari, Vanja Cialei, and Nicoletta Barbabietola, "Measurement of the Fungal Deteriorating Potential in the Dust of Indoor Environments," e-Preservation Science Journal 7 (2010): 29-34, www.morana-rtd.com/e-preservationscience/2010/Pinzari-31-05-2008.pdf (accessed June 15, 2011); Irene Arroyo, "The Roles of Fungi in the Deterioration of Movable and Immovable Cultural Heritage," e-Conservation Magazine no. 9 (2009): 40-50, www.e-conser vationline.com/content/view/748 (accessed June 15, 2011); Susana López-Aparicio, Terje Grøntoft, and Elin Dahlin, “Air Quality Assessment in Cultural Heritage Institutions Using EWO Dosimeters," E-Preservation Science Journal 7 (2010): 96-101, www.morana-rtd.com/e-preservationscience/2010/ Lopez-Aparicio-22-04-2010.pdf (accessed June 15, 2011).

58. Carmen Pérez, Manuel Cuadrado, and Amparo Cervera, "Understanding University Library Users' Mistreatment of Books," Journal of Academic Librarianship 35, no. 2 (2009): 177-83.

59. Kristin Baum, "Interpreting Deluge: A Story of Collections and Response from the 2008 Iowa Floods," The Bonefolder: An E-Journal for the Bookbinder and Book Artists 5, no. 2 (2009): 48-53, http://digilib.syr.edu/cgi-bin/ showfile.exe?CISOROOT $=/$ bonefolder $\&$ CISOPTR $=63 \&$ file name=64.pdf (accessed June 15, 2011); Stephen Winick and Karla Walker, "Help for Haiti: Library Leads Efforts to Restore Laws, Culture," Library of Congress Information Bulletin 69, no. 4 (2010): 76.

60. Diane B. Lunde and Patricia A. Smith, "Disaster and Security: Colorado State Style," Library \& Archival Security 22, no. 2 (2009): 99-114; S. Victor Fleischer and Mark J. Heppner, "Disaster Planning for Libraries and Archives: What You Need to Know and How to Do It," Library \& Archival Security 22, no. 2 (2009): 125-40.

61. Graham Matthews, Yvonne Smith, and Gemma Knowles, eds., Disaster Management in Archives, Libraries, and Museums (Burlington, Vt.: Ashgate, 2009); Frances C. Wilkinson, Linda K. Lewis, and Nancy K. Dennis, Comprehensive Guide to Emergency Preparedness and Disaster Recovery (Chicago: ACRL, 2010).

62. Jamey L. Harris and Scott R. DiMarco, "Locking Down a University Library-How to Keep People Safe in a Crisis: A Mansfield University of Pennsylvania Perspective," Library \& Archival Security 23, no. 1 (2010): 27-36.

63. Ibid., 28.

64. David Delbert Kruger and Sandra Barstow, "Security in a Fully Functioning Academic Library During Renovation," Library \& Archival Security 22, no. 2 (2009): 85-97.

65. Beth Oehlerts, "Inventory: Risk Identification and More,"
Library \& Archival Security 22, no. 3 (2009): 73-83.

66. Ibid., 73 .

67. Thomas Galbraith and Ann-Louise Seago, "Conservation of Manuscripts and Books: Considerations on Insurance and Risk Reduction," Feliciter 55, no. 2 (2009): 54-55.

68. Anna E. Bülow, "Collection Management Using Preservation Risk Assessment," Journal of the Institute of Conservation 33, no. 1 (2010): 65-78.

69. Richard J. Cox et al., "A Different Kind of Archival Security: Three Cases," Library \& Archival Security 22, no. 1 (2009): 33-60.

70. Ariel Neff, "Rewriting History: Forgeries as Crimes against Our Cultural Heritage," Library \& Archival Security 23, no. 1 (2010): 19-25.

71. Ross Griffiths and Andrew Krol, "Insider Theft: Reviews and Recommendations from the Archive and Library Professional Literature," Library \& Archival Security 22, no. 1 (2009): 5-18.

72. Association of Library Collections and Technical Services, Preservation and Reformatting Section, Working Group on Defining Digital Preservation, "Definitions of Digital Preservation," www.ala.org/ala/mgrps/divs/alcts/resources/preserv/ defdigpres0408.cfm (accessed June 28, 2011).

73. Digital Curation Centre, "What Is Digital Curation?" 2010, www.dcc.ac.uk/digital-curation/what-digital-curation (accessed June 29, 2011).

74. Digital Curation Centre, "DCC Curation Lifecycle Model," 2010, www.dcc.ac.uk/resources/curation-lifecycle-model (accessed June 29, 2011).

75. Consultative Committee for Space Data Systems, Reference Model for an Open Archival Information System (OAIS), CCSDS 650.0-B-1 (Washington, D.C.: National Aeronautics and Space Administration, 2002), http://public.ccsds.org/publications/archive/650x0b1.pdf (accessed July 1, 2011).

76. Jean Dryden, "The Open Archival Information System Reference Model," Journal of Archival Organization 7, no. 4 (2009): 216.

77. Ross Harvey, Digital Curation: A How-to-Do-It Manual (New York: Neal Schuman, 2010): 34.

78. Panos Constantopoulos et al., "DCC\&U: An Extended Digital Curation Lifecycle Model," International Journal of Digital Curation 4, no. 1 (2009): 34-45, www.ijdc.net/index. php/ijdc/article/viewFile/100/75 (accessed June 16, 2011); David Dubin et al., "Preserving Meaning, Not Just Objects: Semantics and Digital Preservation," Library Trends 57, no. 3 (2009): 595-610.

79. Digital Curation Centre, "SCARP," www.dcc.ac.uk/projects/ scarp (accessed Sept. 12, 2011).

80. Liz Lyon et al., DCC SCARP: Disciplinary Approaches to Sharing, Curation, Reuse and Preservation: Final Report (2010): 4, www.dcc.ac.uk/sites/default/files/documents/scarp/ SCARP-FinalReport-Final-SENT.pdf (accessed June 29, 2011).

81. Agiatis Benardou et al., "Understanding the Information Requirements of Arts and Humanities Scholarship," International Journal of Digital Curation 5, no. 1 (2010): 19, www. ijdc.net/index.php/ijdc/article/viewFile/144/206 (accessed June 16, 2011). 
82. Michael Witt et al., "Constructing Data Curation Profiles," International Journal of Digital Curation 4, no. 3 (2009): 93-103, www.ijdc.net/index.php/ijdc/article/viewFile/137/165 (accessed June 16, 2011).

83. Harvey, Digital Curation.

84. Ibid., 71-72.

85. Library of Congress, "Transfer Tools," http://sourceforge. net/projects/loc-xferutils (accessed Aug. 1, 2011); JHOVE, "JHOVE-JSTOR/Harvard Object Validation Environment," http://hul.harvard.edu/jhove (accessed Aug. 1, 2011); National Library of New Zealand, "Metadata Extraction Tool," http://meta-extractor.sourceforge.net (accessed Aug. 1, 2011); National Archives of Australia, "DPSP: Digital Preservation Software Platform," http://dpsp.sourceforge.net (accessed Aug. 1, 2011).

86. Michael Ashenfelder, "21st Century Shipping Network Data Transfer to the Library of Congress," D-Lib Magazine 15, no. 7/8 (July/August 2009), www.dlib.org/dlib/july09/ ashenfelder/07ashenfelder.html (accessed June 15, 2011); Michael Ashenfelder et al., "NDIIPP Models for Mass Data Transmission and Storage," Library Trends 57, no. 3 (2009): 541-55.

87. Stephen Abrams, Sheila Morrissey, and Tom Cramer, “What? So What': The Next-Generation JHOVE2 Architecture for Format-Aware Characterization," International Journal of Digital Curation 4, no. 3 (2009): 123-36, www.ijdc.net/index. php/ijdc/article/view/139/174 (accessed June 16, 2011).

88. Patricia Hswe et al., "The Web Archives Workbench (WAW) Tool Suite: Taking an Archival Approach to the Preservation of Web Content," Library Trends 57, no. 3 (2009): 442-60.

89. Priscilla Caplan, "The Florida Digital Archive and DAITSS: A Model for Digital Preservation," Library Hi Tech 28, no. 2 (2010): 224-34.

90. Stephen Abrams, John Kunze, and David Loy, "An Emergent Micro-Services Approach to Digital Curation Infrastructure," International Journal of Digital Curation 5, no. 1 (2010): 172, www.ijdc.net/index.php/ijdc/article/viewFile/154/217 (accessed June 16, 2011).

91. Andrea Goethals, "The Unified Digital Formats Registry," Information Standards Quarterly 22, no. 2 (2010): 26-29; Peter Burnhill and Fred Guy, "Piloting an E-Journals Preservation Registry Service (PEPRS)," The Serials Librarian 58, no. 1-4 (2010): 117-26.

92. Rainer Schmidt et al., "A Framework for Distributed Preservation Workflows," International Journal of Digital Curation 5, no. 1 (2010): 205-17, www.ijdc.net/index.php/ijdc/article/ viewFile/157/220 (accessed June 16, 2011).

93. Richard Pearce-Moses, "The PeDALS Project," Against the Grain 21, no. 2 (2009): 40, 42-43.

94. Victoria Reich, "From Dark Archive to Open Access: CLOCKSS Trigger Event Lessons," Against the Grain 21, no. 2 (2009): 24, 26, 28.

95. Heather Briston and Karen Estlund, "From Passive to Active Preservation of Electronic Records," Ariadne no. 65 (Oct. 2010), www.ariadne.ac.uk/issue65/briston-estlund (accessed June 15, 2011); Elizabeth A. Novara, "Digitization and Researcher Demand: Digital Imaging Workflows at the University of Maryland Libraries," OCLC Systems \& Services 26, no. 3 (2010): 166-76.

96. PREMIS documentation is available at Library of Congress, Standards, PREMIS Home, www.loc.gov/standards/premis (accessed Sept. 21, 2011). Version 2.1 was released in early 2011.

97. Sally Vermaaten, "A Checklist and a Case for Documenting PREMIS-METS Decisions in a METS Profile,” D-Lib Magazine 16, no. 9/10 (2010), www.dlib.org/dlib/september10/ vermaaten/09vermaaten.html (accessed June 15, 2011). See also Devan Ray Donaldson and Paul Conway, "Implementing PREMIS: A Case Study of the Florida Digital Archive," Library Hi Tech 28, no. 2 (2010): 273-89; and Priscilla Caplan, Understanding PREMIS (Washington, D.C.: Library of Congress, 2009), www.loc.gov/standards/premis/understanding-premis.pdf (accessed Sept. 21, 2011).

98. Priscilla Caplan, William R. Kehoe, and Joseph Pawletko, "Towards Interoperable Preservation Repositories: TIPR," International Journal of Digital Curation 5, no. 1 (2010): 34-45, www.ijdc.net/index.php/ijdc/article/viewFile/145/207 (accessed June 16, 2011).

99. Jane Johnson Otto, “A Sound Strategy for Preservation: Adapting Audio Engineering Society Technical Metadata for Use in Multimedia Repositories," Cataloging \& Classification Quarterly 48, no. 5 (2010): 403-22.

100. Kai Naumann, Christian Keitel, and Rolf Lang, "One for Many: A Metadata Concept for Mixed Digital Content at a State Archive," International Journal of Digital Curation 4, no. 2 (2009): 80-92, www.ijdc.net/index.php/ijdc/article/ viewFile/120/123 (accessed June 16, 2011).

101. Brian Matthews et al., "Using a Core Scientific Metadata Model in Large-Scale Facilities," International Journal of Digital Curation 5, no. 1 (2010): 106-18, www.ijdc.net/index. php/ijdc/article/viewFile/149/211 (accessed June 16, 2011).

102. Ibid., 108-9.

103. Clément Oury, WARC Implementation Guidelines, Version 1.0, 2009, www.netpreserve.org/publications/WARC_Guidelines_v1.pdf (accessed June 17, 2011).

104. Peter Sefton et al., "Embedding Metadata and Other Semantics in Word Processing Documents," International Journal of Digital Curation 4, no. 2 (2009): 93-106, www.ijdc.net/index. php/ijdc/article/viewFile/121/132 (accessed June 16, 2011).

105. Harvey, Digital Curation: A How-to-Do-It Manual, 57; Ronald Jantz, "An Institutional Framework for Creating Authentic Digital Objects," International Journal of Digital Curation 4, no. 1 (2009): 71-83, www.ijdc.net/index.php/ ijdc/article/viewFile/103/86 (accessed June 16, 2011); Henry M. Gladney, "Long-Term Preservation of Digital Records: Trustworthy Digital Objects," American Archivist 72, no. 2 (2009): 401-35.

106. Gareth Knight and Maureen Pennock, "Data without Meaning: Establishing the Significant Properties of Digital Research," International Journal of Digital Curation 4, no. 1 (2009): 159-74, www.ijdc.net/index.php/ijdc/article/viewFile/110/87 (accessed June 16, 2011).

107. Harvey, Digital Curation, 120.

108. Geoffrey Yeo, “'Nothing Is the Same as Something Else': Significant Properties and Notions of Identity and Originality," Archival Science 10, no. 2 (2010): 85-116. 
109. Liz Bishoff, "Digital Preservation Plan: Ensuring Long Term Access and Authenticity of Digital Collections," Information Standards Quarterly 22, no. 2 (2010): 20-25.

110. Trustworthy Repositories Audit \& Certification: Criteria and Checklist, version 1.0 (Chicago: Center for Research Libraries; Dublin, Ohio: OCLC, 2007), www.crl.edu/sites/default/ files/attachments/pages/trac_0.pdf (accessed June 30, 2011).

111. Gail Steinhart, Dianne Dietrich, and Ann Green, "Establishing Trust in a Chain of Preservation: The TRAC Checklist Applied to a Data Staging Repository (DataStaR)," D-Lib Magazine 15, no. 9/10 (2009), www.dlib.org/dlib/september 09/steinhart/09steinhart.html (accessed June 15, 2011); Robert R. Downs and Robert S. Chen, "Self-Assessment of a Long-Term Archive for Interdisciplinary Scientific Data as a Trustworthy Digital Repository," Journal of Digital Information 11, no. 1 (2010), http://journals.tdl.org/jodi/article/ view/753/642 (accessed June 16, 2011).

112. Robin L. Dale and Emily B. Gore, "Process Models and the Development of Trustworthy Digital Repositories," Information Standards Quarterly 22, no. 2 (2010): 14-19.

113. "DRAMBORA: About," www.repositoryaudit.eu/about (accessed July 1, 2011).

114. Perla Innocenti and Giuseppina Vullo, "Assessing the Preservation of Institutional Repositories with DRAMBORA: Case Studies from the University of Glasgow," Bollettino AIB 49, no. 2 (2009): 139-56, www.aib.it/aib/boll/2009/0902139.htm (accessed June 15, 2011).

115. Jose Barateiro et al., "Designing Digital Preservation Solutions: A Risk Management-Based Approach," International Journal of Digital Curation 5, no. 1 (2010): 4-17, www.ijdc .net/index.php/ijdc/article/viewFile/143/205 (accessed June 16, 2011).

116. CALIPR can be found at http://sunsite.berkeley.edu/CALIPR (accessed July 4, 2011); dPlan can be found at www.dplan.org (accessed July 4, 2011).

117. PLANETS, "Plato: The Preservation Planning Tool," www.ifs .tuwien.ac.at/dp/plato/intro.html (accessed July 1, 2011).

118. Christoph Becker, Hannes Kulovits, and Andreas Rauber, "Trustworthy Preservation Planning with Plato," ERCIM News, no. 80 (2010): 24-25, http://ercim-news.ercim.eu/images/stories/EN80/EN80-web.pdf (accessed Sept. 18, 2011).

119. William G. LeFurgy, "NDIIPP Partner Perspectives on Economic Sustainability," Library Trends 57, no. 3 (2009): 413-26. See also Tyler O. Walters and Katherine Skinner,
"Economics, Sustainability, and the Cooperative Model in Digital Preservation," Library Hi Tech 28, no. 2 (2010): 83-92.

120. Blue Ribbon Task Force on Sustainable Digital Preservation and Access, Sustainable Economics for a Digital Planet: Ensuring Long-Term Access to Digital Information, Feb. 2010, http://brtf.sdsc.edu/biblio/BRTF_Final_Report.pdf (accessed June 18, 2011).

121. Nancy L. Maron, K. Kirby Smith, and Matthew Loy, Sustaining Digital Resources: An On-the-Ground View of Projects Today, 2009, www.ithaka.org/ithaka-s-r/research/ithaka-case -studies-in-sustainability/report/SCA_Ithaka_SustainingDigitalResources_Report.pdf (accessed June 17, 2011).

122. Pauline Sinclair and Amir Bernstein, An Emerging Market: Establishing Demand for Digital Preservation Tools and Services, 2010, www.planets-project.eu/docs/reports/Planets -VENDOR-White-Paperv4.pdf (accessed Sept. 18, 2011).

123. Samuel Jones, "It's a Material World," Studies in Conservation 55 (2010): 242-49.

124. Graham Pryor and Martin Donnelly, "Skilling up to Do Data: Whose Role, Whose Responsibility, Whose Career?" International Journal of Digital Curation 2, no. 4 (2009): 158-70, www.ijdc.net/index.php/ijdc/article/viewFile/126/133 (accessed June 16, 2011).

125. Lisa M. Given and Lianne McTavish, "What's Old Is New Again: The Reconvergence of Libraries, Archives, and Museums in the Digital Age," Library Quarterly 80, no. 1 (2010): 7-32.

126. Hans-ChristophvonImhoff, "AspectsandDevelopmentofConservator-Restorer's Profession since WWII," $e$-Conservation Magazine no. 8 (2009): 53-61, www.e-conservationline.com/ content/view/717 (accessed June 15, 2011).

127. Jeannette Bastian et al., "Building a Virtual Archives and Preservation Curriculum Laboratory at Simmons College: A Case Study in Collaborative Construction," Journal of Education for Library o Information Science 51, no. 4 (2010): 241-50

128. Mary Molinaro, "How Do You Know What You Don't Know? Digital Preservation Education," Information Standards Quarterly 22, no. 2 (2010): 45-47.

129. Ibid., 47.

130. Library of Congress, "Digital Preservation Outreach and Education," www.digitalpreservation.gov/education/index .html (accessed July 4, 2011).

131. Conway, "Preservation in the Age of Google," 76. 